\title{
Associations of MYF5 gene polymorphisms with meat quality traits in different domestic pig (Sus scrofa) populations
}

\author{
Min Liu, Jian Peng, Dequan Xu, Rong Zheng, Feng'e Li, Jialian Li, Bo Zuo, Minggang Lei, \\ Yuanzhu Xiong, Changyan Deng and Siwen Jiang \\ Agriculture Ministry Key Laboratory of Swine Genetics and Breeding, Key Lab of Agricultural Animal \\ Genetics, Breeding and Reproduction of Ministry of Education, Huazhong Agricultural University, Wuhan, \\ P.R. China
}

\begin{abstract}
The MYF5 gene is first inducibly expressed in muscle cell during embryonic muscle development and plays an important role in regulating the differentiation of skeletal muscle precursors. In this study we used PCR-RFLP to investigate two pig (Sus scrofa) populations $(n=302)$ for two MYF5 gene polymorphisms, a previously unreported novel Met-Leu shift single nucleotide polymorphism (SNP) MYF5/Hsp92/l located on exon 1 and the previously identified intron $1 \mathrm{MYF5} / \mathrm{Hinfl}$ SNP. Haplotype and association analysis showed that haplotypes of the two SNPs were significantly associated with drip loss rate (DLR, $\mathrm{p}<0.05)$, water holding capacity (WHC, $\mathrm{p}<0.05)$, biceps femoris meat color value (MCV2, $p<0.05)$, biceps femoris marbling score (MM2, $p<0.01)$, longissimus dorsi intramuscular fat percentage (IMF, $\mathrm{p}<0.01)$ and longissimus dorsi Water moisture content $(\mathrm{WM}, \mathrm{p}<0.01)$ in the population 2 . However, further studies are needed to confirm these preliminary results.
\end{abstract}

Key words: meat quality, MYF5 gene, pigs, polymorphism, Sus scrofa).

Received: May 14, 2006; Accepted: September 29, 2006.

\section{Introduction}

Continued genetic improvement of domestic pigs (Sus scrofa) requires molecular markers to assist selection. In some cases both genes and the underlying causal mutation have been identified by the candidate gene approach (Harlizius and van der Lende, 2001; Li et al., 2002; Xu et al., 2005). Animal breeders have started applying markerassisted selection to improve the quality and performance of livestock (van der Steen et al., 2005) and genetic polymorphisms (marker loci) significantly associated with important traits have become very useful tools.

After slaughtering an animal muscle tissue becomes meat and meat quality traits, controlled by multiple genes, are economically important traits in all animals reared for meat production, including pigs (Zhao et al., 2004). Myogenic regulatory factors (MRF) are involved in muscle development from commitment and proliferation through muscle fiber formation and postnatal muscle maturation and function (Hughes et al., 1999). The known myogenic regulatory factors are the MYOD1, MYF5, MYOG (myogenin) and MYF6 (MRF4) genes which encode highly

Send correspondence to Si-Wen Jiang. College of Animal Science and Technology, Huazhong Agricultural University, Wuhan 430070, P.R. China. E-mail: jiangsiwen@ mail.hzau.edu.cn. conserved basic helix-loop-helix (bHLH) proteins (Olson and Klein, 1994). The MYF5 gene (Ott et al., 1991) is first inducibly expressed in muscle cells during embryonic muscle development, with many discrete regulatory elements being involved in the activation and maintenance of MYF5 gene expression in the various muscle precursor populations (Teboul et al., 2002). The effects of MYF5 gene restriction fragment length polymorphism (RFLP) on carcass traits have been described by various authors (Stratil and Cepica, 1999; te Pas et al., 1999; Cieslak et al., 2002; Urbanski and Kuryl, 2004) and this gene has been considered a candidate gene for meat production and meat quality (te Pas, 2004; Carmo et al., 2005). However, few studies on the effect of MYF5 gene polymorphisms on meat quality have, in fact, been published and before such polymorphisms can be used efficiently in breeding and management decisions studies with different polymorphisms in different populations are required to properly characterize any associations of this gene with economically important traits across pig populations.

During the study described in this paper we used the polymerase chain reaction (PCR) and RFLP to identify novel MYF5 gene polymorphisms in pure and crossbred pig populations with the aim of elucidating the relationship between MYF5 genotypes and meat quality traits. 


\section{Materials and Methods}

\section{Animals and data collection}

We examined 302 pigs with documented records, the pigs being divided into two populations: population 1 ( $\mathrm{P} 1$, $\mathrm{n}=130$ ), composed of 28 Yorkshire (Y), 46 Landrace (L), 21 Yorkshire Landrace (YL) and 35 Landrace Yorkshire (LY) pigs; and population $2(\mathrm{P} 2, \mathrm{n}=172)$, consisting of 50 Meishan (M), 78 Yorkshire Meishan (YM) and 44 Meishan Yorkshire (MY) pigs. All the pigs were born and raised at Jingpin pig station, Huazhong Agriculture University, Peoples Republic of China.

At slaughter the pigs were stunned using a head-only electric stun-tong apparatus (SFK Meat Systems, a.m.b.a, Kolding, Denmark) after at least two hours rest, slaughtered by the sticking method, exsanguinated, scalded, mechanically dehaired, eviscerated and weighed. The left side of each carcass was used to assess meat quality. At $45 \mathrm{~min}$ postmortem we used a portable digital $\mathrm{pH}$-Meter (model 646, Knick, Berlin) to measure the $\mathrm{pH}$ of the last thoracic vertebral longissimus dorsi (LD), the biceps femoris (BF) and the semispinalis capitis (SC) muscles. At the same time, we measured the drip loss rate (DLR, \%) and water holding capacity (WHC, \%) by the press technique (Wierbicki and Deatherage, 1958) using a $2.523 \mathrm{~cm}$ diameter $1 \mathrm{~cm}$ high columnar meat sample pressed for 5 min between 36 medium-speed filter papers (Xinhua Paper Industry Co., LTD, China) using a swelling press (Qinchuan Electric Apparatus Factory, China) and an applied force of $35 \mathrm{~kg}$ (Xiong and Deng, 1999).

At one to two hours postmortem we used a reflectometer (Model 43, Diffusion Systems Ltd, UK) to measure the objective meat color value (MCV, normal color value is 15 to 25 ) of the LD muscle (MCV1) on the freshly cut surface of a one $\mathrm{cm}$ thick chop removed from the thorax-waist LD (Hornsey, 1956) and the same chop was also given a subjective color score using a standard 1 to 5 color scale (NPPC, 1991) in which 1 represented a very bright color, 3 normal quail-meat color and 5 a very dark color. The same system was used to score the BF MCV (MCV2) of muscle from the core of a hind leg. A subjective meat marbling (MM) score was also given to the thorax-waist LD (MM1) and BF (MM2) muscles using the international marbling standard (American system) 5-grade marking system scale of 1 to 5 in which 1 indicates that the muscle is devoid of marbling, 2 that it is practically devoid of marbling, 3 that marbling is moderately abundant, 4 that marbling is abundant and 5 that marbling is overly abundant (NPPC, 1991).

One day after slaughter, intramuscular fat percentage (IMF, \%) of the last thoracic vertebral LD was determined by chloroform-methanol extraction (Bligh and Dyer, 1959). Water moisture content (WM, \%) was measured in a drying oven at $102{ }^{\circ} \mathrm{C}$ for $18 \mathrm{~h}$ (Bourke et al., 1970). Genomic DNA was isolated from blood samples using a standard phenol: chloroform extraction method (Blin and Stafford, 1976).

\section{Primers, amplification and PCR-RFLP analysis}

We designed two PCR primers based on the porcine MYF5 gene sequence (GenBank, accession number Y17154), the MYF5-p1 primer (5'CGGAGAAGATGGA CCTGAT3' and 5'ATTTCCTCTTGCACGCTTT3') amplifying 243 base pairs (bp) of exon 1 of the MYF5 gene and the MYF5-p2 primer (5'GAGACGGGTGGCTGTGAA T3' and 5'AGGCTGAG AATCGGTGCTG3') amplifying 1193 bp of intron 1 and 2 and exon 2 of the MYF5 gene.

The PCR amplification was carried out in a $20 \mu \mathrm{L}$ final volume containing $25 \mathrm{ng}$ of genomic DNA as template, $0.25 \mu \mathrm{M}$ of each dNTP (MBI Fermentas, Lithuania), $0.25 \mu \mathrm{M}$ of each primer and 1 unit of Taq polymerase (Biostar Internation, Canada) in 1PCR reaction buffer (Biostar Internation, Canada). The PCR conditions consisted of an initial denaturation at $95{ }^{\circ} \mathrm{C}$ for $4 \mathrm{~min}$, followed by 35 cycles of denaturation at $94{ }^{\circ} \mathrm{C}$ for $45 \mathrm{~s}$, annealing at $57^{\circ} \mathrm{C}$ for $M Y F 5$-p 1 or $63{ }^{\circ} \mathrm{C}$ for $M Y F 5$-p 2 for $45 \mathrm{~s}$ and extension at $72{ }^{\circ} \mathrm{C}$ for $1 \mathrm{~min}$, with a final $72{ }^{\circ} \mathrm{C}$ extension for $10 \mathrm{~min}$.

The MYF5 alleles were analyzed using a RFLP protocol in which $8.5 \mu \mathrm{L}$ of the PCR products were digested with 5 units of restriction enzyme (Hsp92II for the MYF5-p1 primer, HinfI for the MYF5-p2 primer) at $37^{\circ} \mathrm{C}$ for $4 \mathrm{~h}$ in $10 \mu \mathrm{L}$ of 1 buffer and the digestion products separated by electrophoreses on $1.5 \%(\mathrm{w} / \mathrm{v})$ agarose gels using 1TAE buffer (Sambrook et al., 1989), the gels being stained with ethidium bromide.

\section{Statistical analysis}

Associations between the MYF5 gene haplotypes and meat quality traits were evaluated using the least square method of the GLM (General Linear Models) procedure and the Statistical Analysis Software version 8.0 (SAS Institute Inc., Cary, USA). The model used to analyze the data was assumed to be:

$$
Y_{i j k l m}=\grave{i}+S_{i}+B_{j}+G_{k}+D_{l}+P_{m}+b_{i j k l m} X_{i j k l m}+e_{i j k l m}
$$

where $Y_{i j k l m}$ is the observation of the trait; $i$ is the population mean, $S_{i}$ is the effect of ith sex ( $i=1$ for male or 0 for female), $B_{j}$ is the effect of $j^{\text {th }}$ breed, $G_{k}$ is the effect of kth haplotype, $D_{l}$ is the effect of boars, $P_{m}$ is the batch effect, $b_{i j k l m}$ is the regression coefficient of the slaughter age and $e_{i j k l m}$ is the random residue.

\section{Results}

\section{Genotype frequencies in the different populations}

Two fragments, MYF5-p1 (243 bp) and MYF5-p2 (1193 bp) were PCR amplified and sequenced from genomic DNA. Multiple alignments of the sequences of six indi- 
vidual samples ( 2 Yorkshire, 2 Landrace and 2 Meishan pigs) allowed the identification of a novel single nucleotide polymorphism (SNP) adenine to cytosine (methionine (ATG) to leucine (CTG) shift) substitution (MYF5/ Hsp92II, detected with the MYF5-p1 primer) in exon 1 and a previously described cytosine/guanine mutation (MYF5/ HinfI, detected with the MYF5-p2 primer) in intron 1 (te Pas et al., 1999). We applied the Hsp92II and HinfI PCR-RFLP protocols to genotyping the exon 1 and intron 1 mutations in 302 pigs with phenotypic records and designated the MYF5-p2 primer MYF5/HinfI genotypes as AA $(1.19 \mathrm{~kb})$, $\mathrm{AB}(1.19 \mathrm{~kb}+729 \mathrm{bp}+464 \mathrm{bp})$ and $\mathrm{BB}(729 \mathrm{bp}+464 \mathrm{bp})$, while the MYF5-p1 primer MYF5/Hsp92II genotypes as $\mathrm{CC}(243 \mathrm{bp}), \mathrm{CD}(243 \mathrm{bp}+210 \mathrm{bp}+33 \mathrm{bp})$ and DD (210 bp $+33 \mathrm{bp})$.

The combined effects of the exon 1 and intron 1 substitutions were estimated as haplotype substitution effects. The combined genotype and haplotype frequencies of the Hsp92II and HinfI MYF5 gene polymorphisms for pigs with records in the two populations studied are shown in Table 1. The HinfI locus had three genotypes in the population 1 and two genotypes (AA and $\mathrm{AB}$ ) in population 2 . The Hsp92II locus was monomorphic in population 1, where only the DD genotype was found, but polymorphic in population 2 where all three genotypes (CC, CD and DD) were detected (Table 1). In population 2 the values in Table 1 suggest the presence of six haplotypes $(\mathrm{AA} / \mathrm{CC}, \mathrm{AA} / \mathrm{CD}$, $\mathrm{AA} / \mathrm{DD}, \mathrm{AB} / \mathrm{CC}, \mathrm{AB} / \mathrm{CD}$ and $\mathrm{AB} / \mathrm{DD})$ but since the $A B / C C$ haplotype was detected in only one pig we excluded this pig and the $\mathrm{AB} / \mathrm{CC}$ haplotype from the association analyses. Moreover, only three of the nine possible genotypic combinations of the two polymorphisms were recorded in population 1. Table 1 also shows that the AA/DD haplotype was present at high frequencies in both population $1(0.785)$ and $2(0.529)$.

\section{Relationship between MYF5 genotypes and meat quality traits}

In population 1 there were only three MYF5 haplotypes (AA/DD, $\mathrm{AB} / \mathrm{DD}$ and $\mathrm{BB} / \mathrm{DD})$ but these did not differ for any meat quality trait analyzed (data not shown). We focused our association analysis on the five population 2 haplotypes (AA/CC, $\mathrm{AA} / \mathrm{CD}, \mathrm{AA} / \mathrm{DD}, \mathrm{AB} / \mathrm{CD}$ and $A B / D D$ ) and found statistically highly significant associations with the MM2, IMF and WM traits and significant associations with the DLR, WHC and MCV2 traits (Table 2). For the DLR and WHC traits the effect for the AA/CD haplotype was significantly different $(p<0.05)$ to the AA/DD haplotype, replacing the AA/DD haplotype by the AA/CD haplotype would significantly decrease WHC by $0.78 \%$ and increase the DLR by $0.583 \%$. For the MCV2 trait, the effect of the $\mathrm{AB} / \mathrm{CD}$ haplotype was significantly different $(p<0.05)$ to the $A B / D D$ haplotype in population 2 and replacing the $\mathrm{AB} / \mathrm{DD}$ with $\mathrm{AB} / \mathrm{CD}$ would significantly decrease the MCV2 by 0.597 . The AA/CC haplotype was
Table 1 - Genotypic frequency distributions for the MYF5 gene HinfI and Hsp92II polymorphic loci haplotypes for two pig populations. The number of pigs with records for each genotype frequency is shown in parentheses. Population $1(\mathrm{n}=130)$, composed of 28 Yorkshire, 46 Landrace, 21 Yorkshire $\mathrm{x}$ Landrace and 35 Landrace $\mathrm{x}$ Yorkshire pigs; and population $2(\mathrm{n}=172)$, consisting of 50 Meishan, 78 Yorkshire $\mathrm{x}$ Meishan and 44 Meishan x Yorkshire pigs.

\begin{tabular}{|c|c|c|c|c|}
\hline \multirow{2}{*}{$\begin{array}{l}\text { Population and } \\
\text { HinfI genotype }\end{array}$} & \multicolumn{4}{|c|}{ Hsp92II genotype frequency } \\
\hline & $\mathrm{CC}$ & $\mathrm{CD}$ & DD & Combined \\
\hline \multicolumn{5}{|l|}{ Population 1} \\
\hline AA & 0 & 0 & $0.785(102)$ & $0.785(102)$ \\
\hline $\mathrm{AB}$ & 0 & 0 & $0.192(25)$ & $0.192(25)$ \\
\hline $\mathrm{BB}$ & 0 & 0 & $0.023(3)$ & $0.023(3)$ \\
\hline Combined & 0 & 0 & $1.00(130)$ & $1.000(130)$ \\
\hline \multicolumn{5}{|l|}{ Population 2} \\
\hline AA & $0.052(9)$ & $0.285(49)$ & $0.529(91)$ & $0.866(149)$ \\
\hline $\mathrm{AB}$ & $0.006(1)$ & $0.047(8)$ & $0.081(14)$ & $0.134(23)$ \\
\hline $\mathrm{BB}$ & 0 & 0 & 0 & 0 \\
\hline Combined & $0.058(10)$ & $0.332(57)$ & $0.610(105)$ & $1.000(172)$ \\
\hline
\end{tabular}

associated with the highest significant IMF value $(\mathrm{p}<0.01)$ and the lowest significantly WM value $(\mathrm{p}<0.01)$. In contrast, pigs carrying the $\mathrm{AB} / \mathrm{CD}$ haplotype had the lowest IMF and MM2 values but the highest WM values of all the haplotypes.

\section{Discussion}

Research on mutations in targeted functional genes (candidate genes) and their association with economic traits has been performed to ascertain the genetic basis of production traits and to develop DNA tests as selection tools in pig breeding schemes (de Vries et al., 1998). This approach is a very promising route for the improvement of meat quality, since direct meat quality records are not available for potential breeding animals (Óvilo et al., 2006). A well known example is the gene tests used to remove the Halothane $(H A L)$ and ryanodine receptor $(R N)$ mutations which have undesirable effects on meat quality, these tests having resulted in a clear improvement of the technological quality of the pork produced in many countries (Fujii et al., 1991; Le Roy et al., 2000). In order to deal with growing market segmentation new genetic techniques are needed to adapt technological and sensory qualities to the requirements of processors and consumers (Monin, 2003; Óvilo et al., 2006).

The MYF5 gene plays a key regulatory role in the initiation and development of skeletal muscle and the maintenance of its phenotype, and is thus a candidate gene for involvement in traits related to growth and meat quality (Maak et al., 2006). In our study we constructed and used the MYF5-p1 primer to identify a novel SNP, the Hsp92II polymorphic loci, an adenine to cytosine shift resulting in a methionine (ATG) to leucine (CTG) amino acid substitu- 
Table 2 - Association of haplotypes in the MYF5 gene with the phenotype value of partial meat quality traits in population $2(\mathrm{n}=172)$, consisting of 50 Meishan, 78 Yorkshire x Meishan and 44 Meishan x Yorkshire pigs. Within-trait (i.e. within the same row) significant differences between the genotype classes are indicated by superscripts, lower case at $\mathrm{p}<0.05$ and upper case at $\mathrm{p}<0.01$.

\begin{tabular}{|c|c|c|c|c|c|}
\hline \multirow[b]{2}{*}{ Traits } & \multicolumn{5}{|c|}{ Genotype* (Least square means \pm standard error) } \\
\hline & $\mathrm{AA} / \mathrm{CC}$ & $\mathrm{AA} / \mathrm{CD}$ & $\mathrm{AA} / \mathrm{DD}$ & $\mathrm{AB} / \mathrm{CD}$ & $\mathrm{AB} / \mathrm{DD}$ \\
\hline Drip Loss Rate (DLR, \%) & $5.979 \pm 0.520$ & $6.536 \pm 0.229^{\mathrm{a}}$ & $5.953 \pm 0.161^{\mathrm{b}}$ & $6.059 \pm 0.546$ & $6.425 \pm 0.416$ \\
\hline Water Holding Capacity (WHC, \%) & $91.777 \pm 0.691$ & $91.091 \pm 0.304^{\mathrm{a}}$ & $91.871 \pm 0.214^{\mathrm{b}}$ & $91.772 \pm 0.725$ & $91.242 \pm 0.552$ \\
\hline BF Meat Color Value (MCV2) & $17.144 \pm 0.215$ & $17.257 \pm 0.095$ & $17.317 \pm 0.067$ & $16.943 \pm 0.226^{\mathrm{a}}$ & $17.540 \pm 0.172^{\mathrm{b}}$ \\
\hline BF marbling score (MM2, on a 1 to 5 scale) & $4.142 \pm 0.030$ & $4.131 \pm 0.013^{\mathrm{A}}$ & $4.176 \pm 0.009^{\mathrm{B}}$ & $4.086 \pm 0.031^{\mathrm{Aa}}$ & $4.164 \pm 0.024^{\mathrm{b}}$ \\
\hline Intramuscular fat percentage (IMF, \%) & $4.716 \pm 0.202^{\mathrm{Aa}}$ & $4.082 \pm 0.089^{\mathrm{B}}$ & $4.140 \pm 0.062^{\mathrm{B}}$ & $4.016 \pm 0.212^{\mathrm{b}}$ & $4.101 \pm 0.161^{\mathrm{b}}$ \\
\hline Water moisture content (WM, \%) & $72.654 \pm 0.223^{\mathrm{Aa}}$ & $73.288 \pm 0.098^{\mathrm{B}}$ & $73.228 \pm 0.069^{\mathrm{b}}$ & $73.646 \pm 0.234^{\mathrm{B}}$ & $73.343 \pm 0.179^{b}$ \\
\hline
\end{tabular}

tion in exon 1 of the MYF5 gene and investigated this polymorphism and the previously reported intron 1 HinfI polymorphism (te Pas et al., 1999) in two populations $(\mathrm{n}=324)$.

Te Pas et al. (1999) investigated the HinfI polymorphic site in the first intron of the MYF5 gene and found that the A-allele predominated in the all pig breeds tested (including those tested by us), which is supported by our results (Table 1). However, Te Pas et al. (1999) found no genotypically associated differences for any of the traits investigated (birth weight, weight at slaughter, growth rate, meat weight and subcutaneous fat thickness) in 1216 Yorkshire pigs and concluded that the porcine $M Y F 5$ gene lacks a significant causal mutation affecting these traits, or that the linkage phase of the MYF5/HinfI polymorphism is not in phase with the $M Y F 5$ causal mutation. However, Cieslak et al. (2002) analyzed the MYF5/HinfI locus in 333 unrelated (Pietrain, Zlotnicka Spotted, Polish Landrace, Pietrain (Pietrain Zlotnicka Spotted), Pietrain (Polish Large White Polish Landrace) and Dutch Large White Dutch Landrace) pigs with an equal proportion of young female pigs (gilts) and castrated male (barrows) pigs and found that gilts with the TT RYRl genotype and AA or AB genotype at the $M Y F 5 / H i n f I$ locus had a significantly higher loin eye area and carcass meat content than pigs without this genotype. Thus, it is still difficult to evaluate the effect of the MYF5/HinfI polymorphism and the different results may depend on the pig breed investigated and statistical model used.

Traditionally, one single nucleotide polymorphism (SNP) is used for genotyping and association analysis. However, using haplotypes, which are specific combinations of nucleotides on the same chromosome, will provide more information on the complex relationship between DNA variation and phenotypes than any single SNP can provide (Stephens et al., 2001; Grindflek et al., 2004). Thus, we used the haplotype information to evaluate the relationship between $M Y F 5$ polymorphisms and meat quality traits. Our results showed that two haplotypes, AA/CD and AA/DD, were highly frequent in population 2 and showed significant difference in their effects on drip loss rate $(\mathrm{DLR})(\mathrm{p}<0.05)$ and water holding capacity (WHC) $(\mathrm{p}<0.05)$. This supports the results of Carmo et al. (2005), who found that MYF5 gene allelic variants had a significant effect on DLR, cooking properties and total cooking loss in a divergent F2 pig population $(n=359)$ of Brazilian Piau boars and commercial white females and that an insertion (I) variation in the MYF5 gene is associated with water-holding capacity in the same population. In our work, we also found that there were significant differences in population 2 between the different haplotypes in respect of the biceps femoris meat color value (MCV2, $\mathrm{p}<0.05)$, biceps femoris marbling score (MM2, $\mathrm{p}<0.05)$, longissimus dorsi intramuscular fat percentage (IMF, $\mathrm{p}<0.01)$ and longissimus dorsi moisture content (WM, $\mathrm{p}<0.01)$. Similarly, the differences for MM2 ( $p<0.01)$, IMF $(\mathrm{p}<0.01)$ and WM $(\mathrm{p}<0.01)$ were also found among different MYF5/Hsp92II genotypes in population 2 (data not shown). Thus, the mutation (MYF5/Hsp92II) in coding regions could be responsible for changes in muscle protein structure or function and lead to changes in meat quality. Of course, the mutation is also possible to link to a quantitative trait locus (QTL) or loci. Because MYF5 has been localized to the Sus scrofa chromosome 5 (SSC5) (Soumillion et al., 1997) and a meat quality QTL has been mapped between the MYF5 and SW967 regions of this chromosome in the W x M family (Lee et al., 2003). In addition, the insulin-like growth factor I (IGFI) and MYF6 genes have been located on the same chromosome as the MYF5 gene (Wintero et al., 1994; Vykoukalova et al., 2003).

To better assess the real impact of the effects of the MYF5 gene on meat quality, further investigations are needed to confirm our results, such as an appropriate area for research being the possible effects of other genes in linkage disequilibrium with the MYF5 SNPs.

\section{Acknowledgments}

This work was supported by the National High Technology Research and Development Program of China (863 Program, 2006AA10Z140), the National Natural Science Foundation of China (30371028) and the Key Technologies R \& D Program of Hubei Province of China (2006AA201B24). 


\section{References}

Bligh EG and Dyer WJ (1959) A rapid method of total lipid extraction and purification. Can J Biochem Physiol 37:911917.

Blin N and Stafford DW (1976) A general method for isolation of high molecular weight DNA from eukaryotes. Nucleic Acids Res. 3:2303-2308.

Bourke RS, Nelson KM, Naumann RA and Young OM (1970) Studies of the production and subsequent reduction of swelling in primate: Cerebral cortex under isosmotic conditions in vivo. Exp Brain Res 10:427-446.

Cieslak D, Kuryl J, Kapelanski W, Pierzchala M, Grajewska S and Bocian M (2002) A relationship between genotypes at MYOG, MYF3 and MYF5 loci and carcass meat and fat deposition traits in pigs. Anim Sci Pap Rep 20:77-92.

Carmo FMS, Guimarães SEF, Lopes PS, Pires AV, Guimarães MFM, Silva MVGB, Schierholt AS, Silva KM and Gomide LAM (2005) Association of MYF5 gene allelic variants with production traits in pigs. Genet Mol Biol 28:363-369.

de Vries AG, Sosnicki A, Garnier JP and Plastow GS (1998) The role of major genes and DNA technology in selection for meat quality in pigs. Meat Sci 49:S245-S255.

Fujii J, Otsu K, Zorzato F, de Leon S, Khanna VK, Weiler JE, O'Brien PJ and MacLennan DH (1991) Identification of a mutation in porcine ryanodine receptor associated with malignant hyperthermia. Science 253:448-451.

Grindflek E, Hoen N, Sundvold H, Rothschild MF, Plastow G and Lien S (2004) Investigation of a peroxisome proliferatoractivated receptor gamma haplotype effect on meat quality and carcass traits in pigs. Anim Genet 35:238-241.

Harlizius B and van der Lende T (2001) Contribution of genomics to unravel the physiological background of economically important traits in livestock. Proceedings of $52^{\text {nd }}$ Annual Meeting of the EAAP, pp 1-12, Budapest, Hungary.

Hornsey HC (1956) The color of cooked cured pork. 1. Estimation of the nitric oxide-haem pigments. J Sci Food Agric 7534.

Hughes SM, Chi MM, Lowry OH and Gundersen K (1999) Myogenin induces a shift of enzyme activity from glycolytic to oxidative metabolism in muscles of transgenic mice. $\mathrm{J}$ Cell Biol 145, 633-642.

Le Roy P, Elsen JM, Caritez JC, Talmant A, Juin H, Sellier P and Monin G (2000) Comparison between the three porcine RN genotypes for growth, carcass composition and meat quality traits. Genet Sel Evol 32:165-186.

Lee SS, Chen Y, Moran C, Stratil A, Reiner G, Bartenschlager H, Moser G and Geldermann H (2003) Linkage and QTL mapping for Sus scrofa chromosome 5. J Anim Breed Genet 120:38-44.

Li FE, Xiong YZ, Deng CY, Jiang SW and Zheng R (2002) Frequencies, inheritance of porcine FSH-retroposon and its association with reproductive traits. Asian-Austral J Anim 15:179-183.

Maak S, Neumann K and Swalve HH (2006) Identification and analysis of putative regulatory sequences for the MYF5/ MYF6 locus in different vertebrate species. Gene 379:141147.

Monin G (2003) Genomics: Improving qualitative characteristics and value of meat from pigs. Outlook Agric 32:227-233.

NPPC (1991) Procedures to Evaluate Market Hogs. National Pork Producers Council, Des Moines, IA, pp 1-15.
Olson EN and Klein WH (1994) bHLH factors in muscle development: Dead lines and commitments, what to leave in and what to leave out. Genes \& Dev 8:1-8.

Óvilo C, Fernández A, Rodríguez MC, Nieto M and Silió L (2006) Association of MC4R gene variants with growth, fatness, carcass composition and meat and fat quality traits in heavy pigs. Meat Sci 73:42-47.

Ott MO, Bober E, Lyons G, Arnold H and Buckingham M (1991) Early expression of the myogenic regulatory gene, myf-5, in precursor cells of skeletal muscle in the mouse embryo. Development. 111:1097-107.

Sambrook J, Fritsch EF and Maniatis T (1989) Molecular Cloning: A Laboratory Manual, 2nd edition. Cold Spring Harbor Laboratory Press, New York.

Soumillion A, Rettenberger G, Vergouwe MN, Erkens JH, Lenstra JA and te Pas MF (1997) Assignment of the porcine loci for MYOD1 to chromosome 2 and MYF5 to chromosome 5. Anim Genet 28:37-38.

Stephens JC, Schneider JA, Tanguay DA, Choi J, Acharya T, Stanley SE, Jiang R, et al. (2001) Haplotype variation and linkage disequilibrium in 313 human genes. Science 293:489-493.

Stratil A and Cepica S (1999) Three polymorphisms in the porcine myogenic factor 5 (MYF5) gene detected by PCR-RFLP. Anim Genet 30:79-80.

te Pas MF, Harders FL, Soumillion A, Born L, Buist W and Meuwissen TH (1999) Genetic variation at the porcine $M Y F-5$ gene locus. Lack of association with meat production traits. Mamm Genome 10:123-127.

te Pas MF (2004) Candidate genes for meat production and meat quality - The MRF genes. Anim Sci Pap Rep 22:115-118.

Teboul L, Hadchouel J, Daubas P, Summerbell D, Buckingham M and Rigby PW (2002) The early epaxial enhancer is essential for the initial expression of the skeletal muscle determination gene Myf5 but not for subsequent, multiple phases of somitic myogenesis. Development 129:4571-4580.

Urbanski P and Kuryl J (2004) New SNPs in the coding and 5' flanking regions of porcine MYOD1 (MYF3) and MYF5 genes. J Appl Genet 45:325-329.

van der Steen HAM, Prall GFW and Plastow GS (2005) Application of genomics to the pork industry. J Anim Sci 83:E1-E8.

Vykoukalova Z, Knoll A, Dvorak J, Rohrer GA and Cepica S (2003) Linkage and radiation hybrid mapping of the porcine MYF6 gene to chromosome 5. Anim Genet 34:238-240.

Wintero AK, Fredholm M and Andersson L (1994) Assignment of the gene for porcine insulin-like growth factor 1 (IGF1) to chromosome 5 by linkage mapping. Anim Genet 25:37-39.

Wierbicki E and Deatherage FE (1958) Determination of water holding capacity of fresh meats. J Agric Food Chem 58:387.

Xiong YZ and Deng CY (1999) Principle and Method of Swine Testing. Chinese Agriculture Press, Beijing, 84 pp.

Xu DQ, Xiong YZ, Liu M, Lan J, Ling XF, Deng CY and Jiang SW (2005) Association analyses with carcass traits in the porcine KIAA1717 and HUMMLC2B genes. Asian-Austral J Anim 18:1519-1523.

Zhao Q, Davis ME and Hines HC (2004) Associations of polymorphisms in the pit-1 gene with growth and carcass traits in the Angus beef cattle. J Anim Sci 82:2229-2233.

Associate Editor: Luiz Lehmann Coutinho 